\title{
Patenting motives, technology strategies, and open innovation
}

\section{Accepted for publication (forthcoming) in Management Decision (2017)}

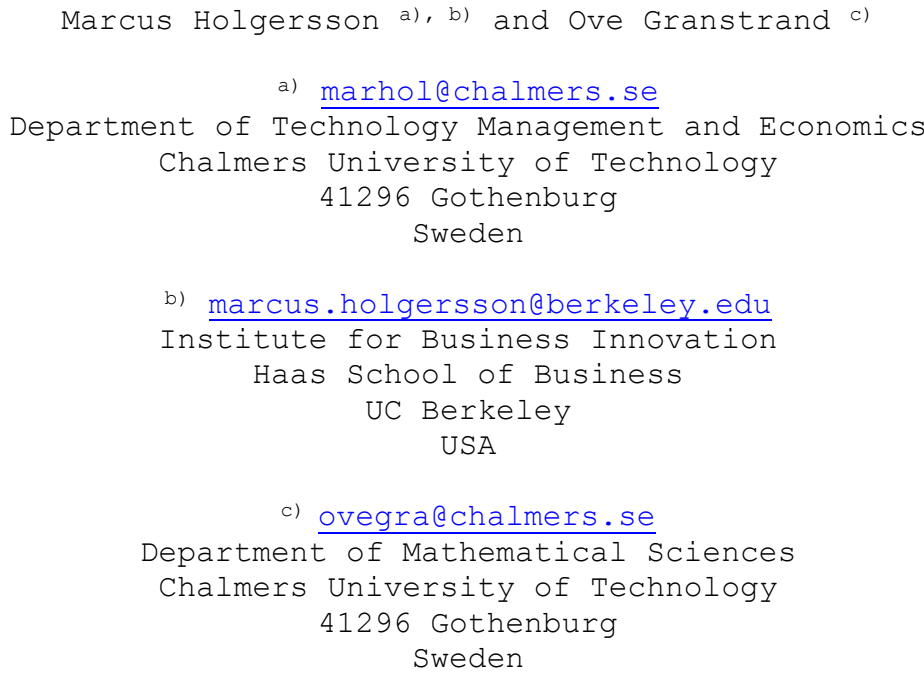

Abstract

Purpose

The purpose of this study is to empirically investigate firms' motives to patent in general, and more specifically how some of these motives depend upon firms' technology strategies and especially their level of open innovation.

Design/methodology/approach

The paper is based on a questionnaire survey sent to CTOs (or equivalent) of the largest R\&D spenders among Swedish large firms (e.g., ABB, AstraZeneca, Ericsson, and Volvo) and among Swedish small and mediumsized enterprises. Principal component analysis and multiple linear regressions were used to check the impact from open innovation upon the importance of 21 different motives to patent, with a specific focus on protection and bargaining related motives.

\section{Findings}

The most important motive to patent is to protect product technologies, but protecting freedom to operate is almost as important, followed by a number of other motives. Increasing importance of open innovation in firms is related to stronger bargaining motives to patent, and even stronger protection motives. In fact, when comparing with closed innovation the results show that open innovation is more strongly positively related with all different motives to patent except for one (to attract customers). This indicates that firms find it more important to patent when engaged in open innovation than when engaged in closed innovation.

\section{Originality/value}

The paper reports results from the first study that links patenting motives to technology strategies. It contributes to an emerging stream of empirical studies investigating the role of patents in external technology strategies and open innovation, showing that the motives to patent are strengthened within open innovation settings.

Keywords: Patent management; motives to patent; technology strategy; innovation; intellectual property management; open innovation 


\section{Introduction}

Society's dominant motive for having a patent system is to improve the provision of innovations by offering inventors temporary, transferable rights to protect their inventions from imitation enough for capturing or appropriating sufficient returns from their inventions to pay back for their R\&D in return for enabling disclosure of the inventions. Since the dawn of the pro-patent era in the 1980s the attention to patenting among firms has increased (Bhaskarabhatla and Hegde, 2014, Granstrand, 1999), and patenting decisions are now increasingly perceived as important strategic considerations. Firms do no longer patent only to prevent imitation, but they have several other motives to patent, such as to obtain bargaining power or to improve the corporate image (e.g., Arundel et al., 1995, Cohen et al., 2000, Duguet and Kabla, 1998, Holgersson, 2013, Mihm et al., 2015), and there has been a surge, or even explosion, in patenting (Hall, 2004, Hu and Jefferson, 2009, Kortum and Lerner, 1998).

A parallel trend has been the increasing attention to and use of various forms of external technology strategies, or in other terms open innovation (Chesbrough, 2003b). While patenting may seem contradictory to open innovation, several scholars have pointed at the enabling role of patents for such interorganizational innovation processes (e.g., Chesbrough, 2003a, Granstrand, 2006, Merges, 2011) and for various forms of technology trade (e.g., Arora et al., 2001, Arrow, 1962, de Rassenfosse et al., 2016, Tietze, 2012). Much recent research has also pointed at the importance of integrating patent strategy with firm strategy in general and technology strategy more specifically. For example, Alexy et al. (2009) argue that there needs to be an alignment between the engagement in open innovation and firms' patent strategies, Manzini and Lazzarotti (2015) point at the different roles various intellectual property rights (IPRs) can play throughout an open innovation process, and Henkel et al. (2013), Bogers (2011), Granstrand and Holgersson (2014), and Holgersson (2012) in various ways emphasize the roles patents can play to control and govern interorganizational technology strategies. However, the patent system has also received increasing criticism for being overused and misused by various actors (Burk and Lemley, 2009, Jaffe and Lerner, 2004), and especially for disabling cumulative innovation across firm boundaries (Bessen and Meurer, 2008, Boldrin and Levine, 2008, 2013, Brüggemann et al., 2016).

Given these developments, there is a need to understand the multifaceted motive structure underlying the decision to patent, and how firms' technology strategies impact the importance of various motives. Our purpose is therefore to empirically investigate firms' motives to patent in general, and more specifically how some of these patenting motives depend upon the firms' technology strategies and especially their level of open/closed innovation. 


\section{Theoretical framework and hypotheses}

There is a relatively rich literature on motives to patent, and the first section below describes how that literature has been used to identify the motives studied here. The section on technology strategies and motives to patent will then develop hypotheses related to the relationship between technology strategies and some of these motives to patent.

\subsection{Motives to patent}

A number of studies have been carried out of the motives (or advantages or rationales) behind firms' decisions to patent, see for example Holgersson (2013) and Mihm et al. (2015) for reviews. As patents fulfill several functions in the economy a plurality of motives to patent can be expected. For example, early studies of patenting motives included to prevent imitation, to avoid litigation, to improve technology negotiation, to enable licensing, and to reward researchers (e.g., Arundel et al., 1995, Duguet and Kabla, 1998). Subsequent studies have included additional motives, such as to block competitors from certain technological areas (Blind et al., 2006, Cohen et al., 2000, Granstrand, 1999), to improve reputation (Blind et al., 2006, Cohen et al., 2000, Thumm, 2004), and to attract capital (Granstrand and Holgersson, 2012, Holgersson, 2013, Keupp et al., 2009, de Rassenfosse, 2012). In this study the latter two motives are subdivided relating to different stakeholders and capital types, respectively. Another important motive for firms to patent is to safeguard their freedom to operate (FTO). Patenting an invention leads to a published patent publication that contributes to prior art. This in turn means that other actors cannot patent that same invention and the patent holder can therefore not be excluded from using its own invention. While this motive has not been explicitly covered by most previous studies, it likely plays an important role in the decision to patent (Granstrand, 1999, Holgersson and Wallin, 2017) and it is therefore included here.

In total we include 21 pre-formulated patenting motives (see Table 3). The motives are grouped into motives for a) protection, b) bargaining, c) improving corporate image, d) attracting external financing, and e) internal motives. This grouping is an extension of the grouping of 10 motives into motives for a) protection, b) bargaining, c) improving corporate image, and d) internal advantages in Granstrand (1999), here adding the group of external financing motives. Blind et al. (2006), using factor analysis, identified five groups of motives: a) protection, b) blockade, c) exchange, d) reputation, and e) incentive. At closer scrutiny the latter five groups identified ex post by Blind et al. (2006) are by and large aligned with the five groups of motives identified ex ante in this study except for the blockade group in the Blind et al. study (grouped with protection motives here) and the external financing 
motive group in this study (grouped with exchange/bargaining motives by Blind et al.).

\subsection{Technology strategies and motives to patent}

Firms may acquire and commercialize technologies through internal R\&D and inhouse production and marketing of products and services. However, there are also many alternatives to this type of internal technology acquisition and commercialization. Firms may for example buy or sell licenses (Granstrand, 2004) or in other ways trade technologies on various technology markets (Arora et al., 2001), for example through patent auctions (Tietze, 2012). Firms may also engage in various forms of organizational setups with various degrees of organizational disintegration in which technologies are acquired and/or commercialized, for example through partnerships, joint ventures, and spin-offs (Granstrand and Sjölander, 1990). All these different types of external technology strategies are sometimes viewed as different forms of open innovation (Chesbrough, 2003b), and more specifically different forms of inbound or outbound open innovation (Enkel et al., 2009, Dahlander and Gann, 2010).

We here use a typology of technology procurement (inbound) and technology exploitation (outbound) strategies originally introduced by Granstrand (1982) with different types of technology strategies ranging from fully vertically integrated ones over quasi-integrated ones to disintegrated ones in a transaction cost framework (Williamson, 1975). This framework was subsequently refined in several research studies. Granstrand and Sjölander (1990) embedded the strategies in a multitechnology context and Granstrand et al. (1992) related the typology to the theory of incomplete contracts and created an index as an operationalization of organizational integration, or in other terms of inbound and outbound openness in innovation, based on the length and strength (binding) of the contractual relations associated with each strategy type, ranging from the use of full employment contracts to the use of spot market contracts and contract free exchange. ${ }^{1}$ The typology is thus based on the different types of contractual relations involved, which is in line with the view of the technology based firm as a nexus of technology related contracts.

On the acquisition/inbound side the typology, which is illustrated in Figure 1, includes a) in-house $R \& D$, and various forms of external acquisition, such as b) acquisition of innovative firms (or business units), c) joint ventures and other forms of collaborative R\&D, d) technology in-licensing, and e) other forms of technology

\footnotetext{
${ }^{1}$ See Granstrand et al. (1997) and Granstrand (1999) for additional empirical use of the typology and Granstrand (1998) for further theorizing about the technology based firm.
} 
purchasing (e.g., contract R\&D). On the commercialization/outbound side the typology analogously includes a) internal exploitation (i.e. with integrated production and/or marketing and sales of technology-based products and services), b) creation of innovative firms (units, spin-offs), c) joint ventures and collaborations, d) technology out-licensing, and e) other forms of technology sales (e.g., contract R\&D). Aside from the in-house $R \& D$ and internal exploitation strategies, these strategies comprise different forms of open innovation (Chesbrough, 2003b). The typology also includes other forms of technology acquisition and exploitation, such as technology scanning, leakage, and loss (cf., Granstrand et al., 1992), but they are not included in our analysis here.

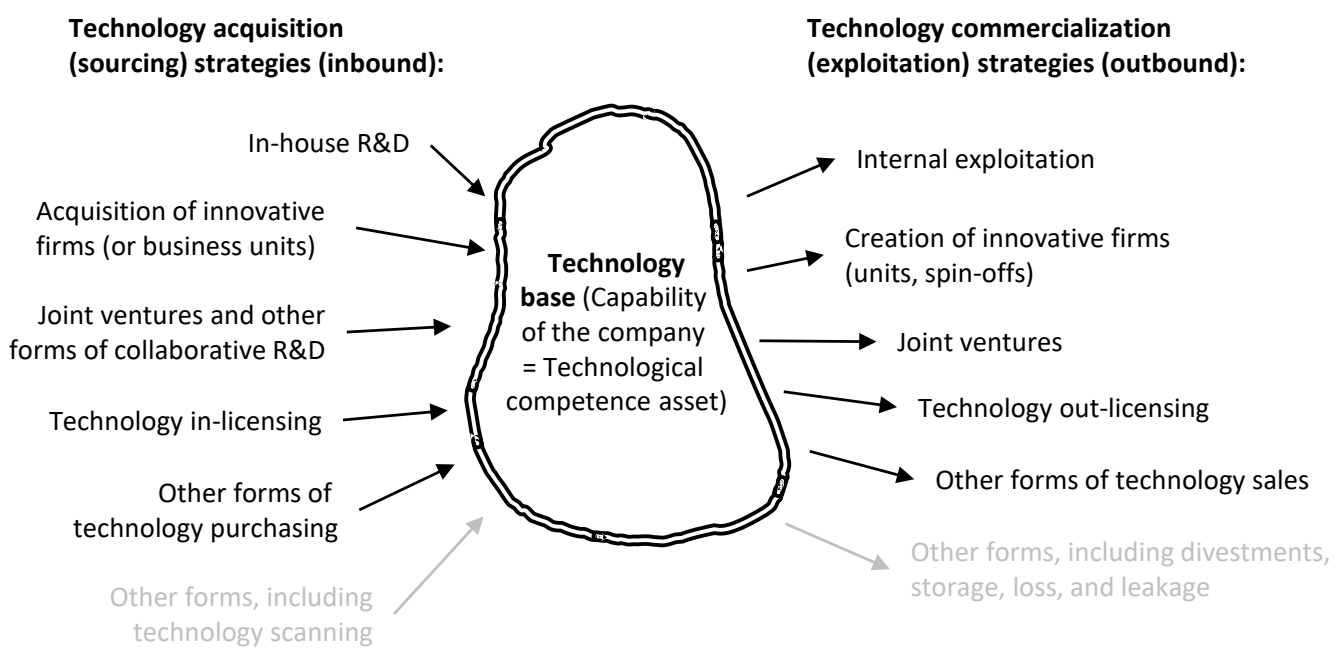

Figure 1 Typology of technology acquisition and commercialization strategies or in other terms different modes of inbound and outbound closed/open innovation (adapted from Granstrand, 1982, and Granstrand et al., 1992)

Previous research has pointed at various ways in which patents may function to enable open innovation, even though there is also literature questioning whether patents enable or inhibit collaborative R\&D (e.g., Alexy et al., 2009, von Hippel, 2005). While our study includes several individual motives across five groups, there are especially two groups of motives that seem to be related to open innovation according to previous literature, namely protection and bargaining motives, and below we develop hypotheses about these relationships.

First, protection motives include protection of product and process technologies, creation of retaliatory power, blocking competitors from certain technology areas, and securing FTO. Several scholars argue that patents may disable knowledge flows and cumulative innovation (Brüggemann et al., 2016), and that when engaged in open innovation, innovators should refrain from protecting their innovations and rather freely reveal them (e.g., Baldwin and von Hippel, 2011, von Hippel and von 
Krogh, 2006). One argument is that innovators who freely share their contributions can in exchange get access to a full design for only a small share of the total design cost, and that freely revealing is therefore a rational choice among non-competitors (Baldwin and von Hippel, 2011). Additionally, firms employing strict patent protection may decrease the amount of complementary inventions developed by other firms (Bhaskarabhatla and Hegde, 2014).

However, even when benefiting from freely revealing some of their inventions, innovators may still benefit from patenting other inventions, employing a selective revealing strategy (Henkel, 2006) which may be especially useful for modular products (Baldwin and Henkel, 2015, Henkel et al., 2013). In addition, much research points at the important function of patents even for innovations that are shared across firms boundaries (Arora and Ceccagnoli, 2006, de Rassenfosse et al., 2016, West, 2006). In such situations there are less possibilities to rely on other protection mechanisms, such as secrecy (e.g., Arundel, 2001) or control of complementary assets (Teece, 1986). In addition, the technology is more at risk to imitation or substitution threats when it is exposed to technology markets or to collaboration partners (Foss et al., 2010, Granstrand and Holgersson, 2014, Pisano and Teece, 2007, Veer et al., 2016), again increasing the need for patent protection.

Not only protection of the focal technology may be of importance. When a firm shares or sells knowledge and technologies, the probability that collaborators would walk into a similar technological pathway increases, in turn increasing the risks for the firm of being blocked by its collaborators' future patents (Granstrand and Holgersson, 2014). ${ }^{2}$ This would increase the importance of patenting to block competitors or collaborators from certain technology areas, to create retaliatory power, and to secure FTO. All of these motives are included in our group of protection motives, and we hypothesize that their importance is positively related with the importance of open innovation strategies.

H1: The importance of protection motives is positively related with the importance of open innovation strategies.

Second, bargaining motives include increasing licensing and cross-licensing possibilities, facilitating R\&D collaborations, and improving bargaining position in standard-setting. Ever since the seminal work by Arrow (1962) the need for patents to enable technology trade has been accepted in theory. The argument is that patents enable codified disclosure of technologies (de Rassenfosse et al., 2016, Zobel et al., 2016) and facilitate technology trade or collaboration (Blind et al., 2006, Bogers,

\footnotetext{
${ }^{2}$ This relates to the concepts of sideground and postground knowledge/technology/IP (Granstrand and Holgersson, 2014).
} 
2011, Chesbrough, 2003a). In these situations the contractual underpinnings created by patents are useful for governing collaboration and trade (Granstrand and Holgersson, 2013, Hagedoorn and Zobel, 2015, Merges, 2011). The perceivable benefits are thus not only related to possibilities of selling licenses. Patents might give better possibilities to access outside technologies through cross-licensing, they might facilitate R\&D collaborations with others, and they might give a better bargaining position in collaborative standard-setting. All these are different individual motives that we group as bargaining motives, and we again hypothesize that their importance is positively related with the importance of open innovation strategies.

H2: The importance of bargaining motives is positively related with the importance of open innovation strategies.

\section{Method}

\subsection{Sampling}

We sent the questionnaire to the 100 largest $R \& D$ spenders (in terms of yearly $R \& D$ expenses) among Swedish national and binational large firms as well as to the 100 largest R\&D spenders among Swedish SMEs. R\&D data was collected from three different sources. In addition to data from financial records (which is incomplete in terms of $R \& D$ expenditures), data was collected from listings of top $R \& D$ investors in the EU (The 2010 EU Industrial R\&D Investment Scoreboard) as well as from listings of top R\&D spenders in the Swedish technology newspaper NyTeknik. Additional company data was collected from the Swedish company database Retriever Business and from annual reports.

Questionnaire data was collected via paper and internet-based surveys during late 2011 and early 2012. 57\% of the large firms and 34\% of the SMEs responded. The total response rate was thus $46 \%^{3}$, and non-respondents were fairly evenly distributed across different levels of $R \& D$ spending. The respondents (large firms; SMEs) were distributed across several industries, including chemistry, biotechnology, pharmaceuticals $(12 \% ; 13 \%)$, electronics, IT, power $(20 \% ; 15 \%)$, mechanical $(18 \% ; 7 \%)$, and other industries $(13 \% ; 2 \%)$. Even though the sample is relatively small, the tail sampling technique (sampling the largest R\&D spenders) enables us to cover a large share of the Swedish corporate R\&D. Needless to say, $R \& D$ expenditures are heavily skewed, with most corporate $R \& D$ being carried out in a few large technology-based companies. In the case of Sweden these include

\footnotetext{
${ }^{3}$ For some firms there are missing data on specific questions.
} 
firms such as Volvo, Ericsson, ABB, AstraZeneca, etc. By focusing on 200 of the largest $R \& D$ spenders, we ensured that we were able to receive responses from the right person within the right firms with a high response rate. ${ }^{4}$ By including two different subsamples of the largest R\&D spenders, large firms and SMEs, we were able to include firms across most sizes, despite the fact that most $R \& D$ expenditures in absolute terms are made by large firms.

Nevertheless, small samples need to be treated with care. In this case no statistical generalization can be made outside the population of the largest R\&D spenders among Swedish large firms and SMEs, even though we see no reason to believe that our results would differ from studies of firms in other countries with similar characteristics.

We made direct contacts with the highest relevant position at each company. The questionnaire was typically sent to the person holding the chief technology officer (CTO), VP R\&D, head of R\&D, or similar position, at each company. Almost all the responses were also given by the intended respondents, with very few exceptions where the questionnaire had trickled down to for example patent managers.

\subsection{Variables}

The technology strategies of the studied firms are investigated by a set of questions inspired by previous research as discussed above. Various strategies are measured with 5-point interval scales (1-5) ranging from 1 (not at all important) to 5 (very important). These relate to strategies with various degrees of organizational integration. In this study we focus on three main strategies for acquiring technologies and three main strategies for commercializing (exploiting) technologies.

The first strategy for acquiring technologies is internal $R \& D$, which is measured by a single item in the questionnaire. The second strategy is what we call inbound organizational extension, which is measured as the maximum value of two different items, including acquisition of innovative firms (or business units) and joint ventures and other forms of collaborative $R \& D$. This strategy relates to various ways of expanding the organizational boundary of the firm to include additional technology or R\&D. The third and final strategy for acquiring technologies is what we call inbound technological extension, which is again measured as the maximum value of two different items, including purchasing of licenses and other forms of

\footnotetext{
${ }^{4}$ Broader and larger sampling would have led to a greater number of responses, at the expense of a decreasing response rate among the firms we wanted to focus on, i.e. the largest R\&D spenders.
} 
technology purchasing, such as contract R\&D. This strategy relates to various ways of purchasing technologies from outside stakeholders. Maximum values are preferred over average values in the two latter technology commercialization strategies, since one firm might focus on only one out of two items, and averaging the two would downplay the importance too much.

The strategies for exploiting or commercializing technologies and the strategies for acquiring or sourcing them correspond one-to-one to each other in that each type of contract links the exploiting party to the acquiring party on a market. The first technology commercialization strategy is internal exploitation through direct investments in production and/or marketing and sales of technology-based products and services. The second strategy is outbound organizational extension, measured as the maximum of creation of innovative firms (units, spin-offs) and joint ventures. The third strategy is outbound technological extension, measured as the maximum of sales of technology licenses and other forms of technology sales (such as performing contract $R \& D$ ).

The different motives to patent are also measured with 5-point interval scales (1-5) ranging from 1 (not at all important) to 5 (very important). The two groups of motives of main interest here are then measured as scales, each one averaging the values over several interval items. These motive groups are "for protection" and "for bargaining". They consist of five and four items, respectively (see question structure in Table 3, which includes the full list of various motives).

Apart from the above independent and dependent variables we include a number of control variables. Firm size is included as a dummy variable being 1 for the sample of large firms and 0 for the sample of SMEs. We also include the 10-logaritm of the total turnover as an additional control variable, since there is size variation within each sub-sample. Much research has pointed at SMEs' lack of resources for properly benefitting from the patent system (e.g., Holgersson, 2013, Kitching and Blackburn, 1998), and their relatively low patent propensity (Mansfield, 1986, Arundel and Kabla, 1998, Brouwer and Kleinknecht, 1999, Chabchoub and Niosi, 2005). Previous research has also indicated that SMEs relative to large firms put larger emphasis on image and financing motives (Blind et al., 2006, Conti et al., 2013, Hoenig and Henkel, 2015, Holgersson, 2013, Holgersson et al., 2016, de Rassenfosse, 2012). Apart from firm size, the level of intellectual property (IP) organization in some sense could impact the motives that firms have to patent, since a firm with a more developed IP organization can probably utilize the patent system better and in more ways than a firm with a less developed IP organization (e.g., Granstrand and Holgersson, 2012). This variable is measured as the sum of positive answers to questions about the firms having 1) a central patent department, 2) a patent/IP manager, and 3) a written corporate-wide patent/IP policy. Thus, the variable ranges from 0 for a low level of IP organization to 3 for a high level of IP 
organization. Finally, dummy variables are included for the four different broad industries, including 1) chemistry, biotechnology, pharmaceuticals, 2) mechanical, 3 ) electronics, IT, power, and 4) other industries. This is important since previous research has found large differences between industries (Holgersson, 2013, Levin et al., 1987, Mansfield, 1986).

Table 1 presents descriptive statistics and correlations across independent variables and control variables. Some observations can be made. First, size (measured by two different controls) is positively correlated with the level of IP organization. Second, size is positively correlated with inbound organizational extension, meaning that large firms in general make more use than SMEs of acquisition of innovative firms (or business units) and joint ventures and other forms of collaborative R\&D. Third, size is negatively correlated with outbound technology extension, meaning that SMEs make more use than large firms of various forms of licensing and technology sales, in line with expectations (e.g., Granstrand, 2004). Fourth and finally, there is a number of significantly positive correlations across technology strategies. This has implications for our continued statistical analysis, which we will cover more in depth below. 
Table 1 Descriptive statistics and correlations, independent and control variables

\begin{tabular}{|c|c|c|c|c|c|c|c|c|c|c|c|c|}
\hline \multirow[b]{2}{*}{ Independent variable: } & \multirow[b]{2}{*}{$\begin{array}{c}\text { Mean } \\
\text { (std. dev.) }\end{array}$} & \multicolumn{11}{|c|}{$\begin{array}{l}\text { Pearson correlation } \\
\text { (significance) }\end{array}$} \\
\hline & & Size sample & $\begin{array}{c}\text { Size } \\
\text { (LogTurnove } \\
\text { r) }\end{array}$ & IP org & ChemistryEtc & $\begin{array}{c}\text { ElectronicsEt } \\
\mathrm{c}\end{array}$ & $\begin{array}{c}\text { MechanicalEt } \\
\text { c }\end{array}$ & $\begin{array}{l}\text { In-house } \\
\text { R\&D }\end{array}$ & $\begin{array}{l}\text { Inbound Org. } \\
\text { Extension }\end{array}$ & $\begin{array}{l}\text { Inbound } \\
\text { Tech. } \\
\text { Extension }\end{array}$ & $\begin{array}{c}\text { Internal } \\
\text { Exploitation }\end{array}$ & $\begin{array}{l}\text { Outbound } \\
\text { Org. } \\
\text { Extension }\end{array}$ \\
\hline Size sample & $\begin{array}{c}.626 \\
(.4864)\end{array}$ & & & & & & & & & & & \\
\hline Size (LogTurnover) & $\begin{array}{c}6.214 \\
(1.116)\end{array}$ & $\begin{array}{l}.783^{* * * *} \\
(.000)\end{array}$ & & & & & & & & & & \\
\hline IP org & $\begin{array}{c}1.473 \\
(1.214)\end{array}$ & $\begin{array}{l}.227^{*} \\
(.030)\end{array}$ & $\begin{array}{l}.250^{*} \\
(.017)\end{array}$ & & & & & & & & & \\
\hline ChemistryEtc & $\begin{array}{c}.253 \\
(.437)\end{array}$ & $\begin{array}{l}-.178^{+} \\
(.091)\end{array}$ & $\begin{array}{l}-.146 \\
(.169)\end{array}$ & $\begin{array}{l}.212^{*} \\
(.043)\end{array}$ & & & & & & & & \\
\hline ElectronicsEtc & $\begin{array}{l}.352 \\
(.480)\end{array}$ & $\begin{array}{l}-.097 \\
(.359)\end{array}$ & $\begin{array}{l}-.182^{+} \\
(.085)\end{array}$ & $\begin{array}{l}-.212^{*} \\
(.044)\end{array}$ & $\begin{array}{c}-.428^{* * *} \\
(.000)\end{array}$ & & & & & & & \\
\hline MechanicalEtc & $\begin{array}{l}.242 \\
(.431)\end{array}$ & $\begin{array}{c}.118 \\
(.266)\end{array}$ & $\begin{array}{l}.182^{+} \\
(.084)\end{array}$ & $\begin{array}{l}.055 \\
(.602)\end{array}$ & $\begin{array}{l}-.328^{* *} \\
(.001)\end{array}$ & $\begin{array}{c}-.416^{* * * *} \\
(.000)\end{array}$ & & & & & & \\
\hline In-house R\&D & $\begin{array}{l}4.453 \\
(.697)\end{array}$ & $\begin{array}{l}.117 \\
(.282)\end{array}$ & $\begin{array}{c}.073 \\
(.506)\end{array}$ & $\begin{array}{c}.119 \\
(.275)\end{array}$ & $\begin{array}{c}.078 \\
(.476)\end{array}$ & $\begin{array}{l}-.041 \\
(.709)\end{array}$ & $\begin{array}{l}-.020 \\
(.852)\end{array}$ & & & & & \\
\hline Inbound Org. Extension & $\begin{array}{l}3.371 \\
(.910)\end{array}$ & $\begin{array}{c}.149 \\
(.175)\end{array}$ & $\begin{array}{l}.200^{+} \\
(.067)\end{array}$ & $\begin{array}{c}.156 \\
(.155)\end{array}$ & $\begin{array}{l}-.094 \\
(.394)\end{array}$ & $\begin{array}{c}.062 \\
(.574)\end{array}$ & $\begin{array}{c}.052 \\
(.638)\end{array}$ & $\begin{array}{c}.057 \\
(.604)\end{array}$ & & & & \\
\hline Inbound Tech. Extension & $\begin{array}{c}2.977 \\
(1.069)\end{array}$ & $\begin{array}{l}-.131 \\
(.231)\end{array}$ & $\begin{array}{l}-.050 \\
(.650)\end{array}$ & $\begin{array}{c}.038 \\
(.729)\end{array}$ & $\begin{array}{c}.063 \\
(.565)\end{array}$ & $\begin{array}{c}.158 \\
(.149)\end{array}$ & $\begin{array}{l}-.167 \\
(.127)\end{array}$ & $\begin{array}{l}-.052 \\
(.638)\end{array}$ & $\begin{array}{l}.395^{* * *} \\
(.000)\end{array}$ & & & \\
\hline Internal Exploitation & $\begin{array}{l}4.306 \\
(.817)\end{array}$ & $\begin{array}{l}.062 \\
(.571)\end{array}$ & $\begin{array}{l}.000 \\
(.998)\end{array}$ & $\begin{array}{c}.054 \\
(.623)\end{array}$ & $\begin{array}{c}.141 \\
(.197)\end{array}$ & $\begin{array}{l}.065 \\
(.554)\end{array}$ & $\begin{array}{l}.120 \\
(.273)\end{array}$ & $\begin{array}{l}.141 \\
(.202)\end{array}$ & $\begin{array}{c}.028 \\
(.802)\end{array}$ & $\begin{array}{l}-.094 \\
(.396)\end{array}$ & & \\
\hline Outbound Org. Extension & $\begin{array}{l}2.565 \\
(1.107)\end{array}$ & $\begin{array}{l}-.140 \\
(.202)\end{array}$ & $\begin{array}{l}-.077 \\
(.486)\end{array}$ & $\begin{array}{c}.025 \\
(.824)\end{array}$ & $\begin{array}{c}.048 \\
(.660)\end{array}$ & $\begin{array}{l}-.041 \\
(.708)\end{array}$ & $\begin{array}{l}-.046 \\
(.675)\end{array}$ & $\begin{array}{l}-.074 \\
(.503)\end{array}$ & $\begin{array}{l}.225^{*} \\
(.040)\end{array}$ & $\begin{array}{c}.072 \\
(.515)\end{array}$ & $\begin{array}{l}-.145 \\
(.190)\end{array}$ & \\
\hline Outbound Tech. Extension & $\begin{array}{l}2.115 \\
1.006\end{array}$ & $\begin{array}{l}-.191^{+} \\
(.095)\end{array}$ & $\begin{array}{l}-.289^{*} \\
(.010)\end{array}$ & $\begin{array}{l}.045 \\
(.696)\end{array}$ & $\begin{array}{c}.013 \\
(.909)\end{array}$ & $\begin{array}{l}.051 \\
(.659)\end{array}$ & $\begin{array}{l}-.095 \\
(.406)\end{array}$ & $\begin{array}{l}.118 \\
(.307)\end{array}$ & $\begin{array}{l}.204^{+} \\
(.076)\end{array}$ & $\begin{array}{l}.179 \\
(.119)\end{array}$ & $\begin{array}{l}-.142 \\
(.217)\end{array}$ & $\begin{array}{l}.429^{* * *} \\
(.000)\end{array}$ \\
\hline
\end{tabular}

Notes:,$+ * * *$, and $* * *$ indicate significance at the $10 \%, 5 \%, 1 \%$, and $0.1 \%$ levels, respectively (2-tailed). Parentheses are presenting standard deviations for means and significance for correlations. 


\subsection{Variable reduction}

The large number of significant correlations across the six technology strategies leads us to believe that there could be one or several latent dimensions. Principal component analysis (PCA) was used to help explore such latent dimensions. ${ }^{5}$ Factorability was examined by the Kaiser-Meyer-Olkin measure of sampling adequacy (0.569), Bartlett's test of sphericity (significant at the $0.1 \%$ level), and anti-image correlation matrix diagonals (all but one larger than 0.5), all in all indicating the usefulness of PCA (e.g., Cerny and Kaiser, 1977, Dziuban and Shirkey, 1974). An orthogonal factor matrix rotation (varimax) was selected, but the results here are robust also for oblique rotation (direct oblimin). The results from the PCA showed that two components have eigenvalues above 1 (indicating that these are the two to include according to the Kaiser criterion), and that these two components together explain $51 \%$ of the variance. The scree plot supports the selection of these two components. The resulting component matrices are presented in Table 2, showing factor loadings above 0.3. Our interpretation of the PCA results is that the first component is an open innovation component that relates to various external technology acquisition and commercialization strategies, while the second component is a closed innovation component that relates to internal technology acquisition and commercialization strategies. These two components resonate well with the purpose of the paper, and they will be used as our independent variables in the continued analysis.

Table 2 Component matrix from factor analysis

\begin{tabular}{lcccc}
\hline & \multicolumn{2}{c}{ Components } & \multicolumn{2}{c}{ Rotated components } \\
\cline { 2 - 4 } & 1 & 2 & 1 & 2 \\
\hline Outbound Org. Extension & .711 & & .723 \\
Outbound Tech. Extension & .687 & & .697 \\
Inbound Org. Extension & .677 & .349 & .674 \\
Inbound Tech. Extension & .601 & & .592 & .765 \\
In-house R\&D & & .774 & & .681 \\
Internal Exploitation & & .645 & & \\
\hline
\end{tabular}

Notes: Coefficients with less than 0,3 factor loading are not shown. Extraction Method: Principal Component Analysis. Rotation Method: Varimax with Kaiser Normalization. Rotation converged in 3 iterations.

\footnotetext{
${ }^{5}$ The statistical analysis is done in SPSS Statistics 22 throughout.
} 


\section{Results}

We present our empirical results here in two sections, in line with the two parts of the purpose. First, we present our results on firms' motives to patent in general. Second, we present our results on how firms' level of open innovation impact the motives to patent, especially protection and bargaining motives.

\subsection{Motives to patent}

The descriptive results show the importance of various motives for patenting, see Table 3 where the results have been split for the two subsamples of large firms and SMEs, respectively. A number of observations can be gleaned right away from Table 3, based on comparisons across motive groups and firm sizes.

First, the most important motive to patent for both large firms and SMEs is to protect product technologies, and protection motives in general, except for process protection, dominate over other groups of motives. The second most important motive is to protect/secure FTO. As described above, FTO refers to the ability to produce and market products and services without infringing other actors' IPRs and interestingly enough firms find that motive almost as important as to protect product technologies. A related motive, number three in average importance, is to block competitors from certain technology areas. This is related to the ability to ensure one's own technological flexibility on the one hand, and the ability to hinder competitors' technological advancements on the other hand (cf. Blind et al., 2006). Moreover, to create retaliatory power through patenting is instrumental for securing both FTO and technological flexibility, and this is the fourth (out of 21) strongest motive to patent for both large firms and SMEs. ${ }^{6}$

Second, the corporate image group of motives comes next in importance on average. The specific motive to improve image towards investors is the second strongest motive among SMEs and significantly stronger than for large firms.

The third group of motives is internal motives to patent. These include to motivate employees and to measure R\&D productivity.

Fourth, motives related to bargaining (e.g. for licensing and cross-licensing and for facilitating $R \& D$ collaborations) are of relatively limited importance, however in general more important for SMEs, especially for selling licenses. Bargaining motives to patent is likely becoming stronger as firms engage in external, or open, technology acquisition and exploitation (i.e., open innovation), requiring bargaining with external partners or parties on technology markets, and then

\footnotetext{
${ }^{6}$ This is in line with the arms race model of patenting (Granstrand, 1999, Jell et al., forthcoming).
} 
especially for small firms forced to or prone to use such exploitation strategies rather than integrating forward into production and marketing. We will return to this below.

Fifth, the group of motives to patent for attracting external financing in various forms is in addition to bargaining a group of non-traditional motives. As a group its importance ranks lowest among the motive groups, while there are some interesting differences between firm sizes. SMEs rate motives related to attracting private capital significantly higher than large firms.

\subsection{Open innovation and motives to patent}

The second part of our purpose addresses the relationship between the importance of open innovation strategies and some of the motives to patent. More specifically, we hypothesize that open innovation strengthen protection $(\mathrm{H} 1)$ as well as bargaining (H2) motives to patent (see above). We perform two multiple linear regressions to test our hypotheses.

Table 4 presents regression results for the first hypothesis, i.e. that the importance of protection motives is positively related with the importance of open innovation strategies. The regression supports Hypothesis 1 at the $0.1 \%$ significance level. The coefficient is even larger for the open innovation component than for the closed innovation component. ${ }^{7}$ This means that increasing importance of open innovation strategies is related to increasing importance of patenting for protection reasons, which is already the strongest motive to patent in general.

The second hypothesis states that the importance of bargaining motives is positively related with the importance of open innovation strategies. There was a relatively low importance of bargaining motives on average (see Table 3). However, the importance of these motives increases with increasing importance of open innovation strategies, see Table 5. Hypothesis 2 is supported at the $10 \%$ significance level. Again, the coefficient is larger for the open innovation component than for the closed innovation component.

7 The difference in coefficients between the open and closed innovation components is not significant, however, which can be tested by calculating the share of overlapping confidence intervals for the beta coefficients (e.g., Cumming 2009, Cumming and Finch, 2005). A larger sample might be needed to find significant differences across coefficients. 
Table 3 Average importance of various motives to patent $(1=$ not at all important; $5=$ very important $)$ with significance of difference in means

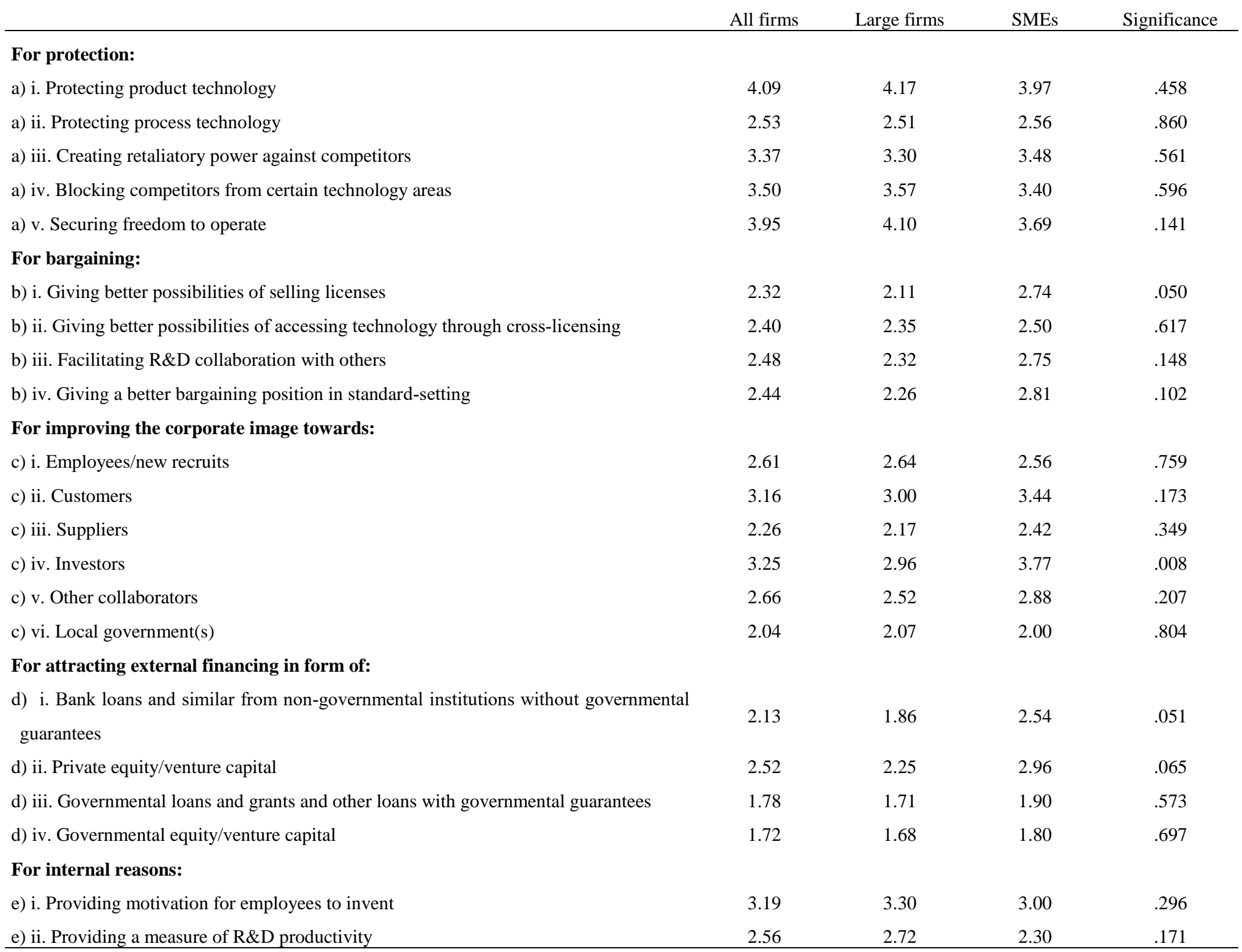

Notes: 2-tailed significance from t-test for equality of means, not assuming equal variances. 
Table 4 Regression results - protection motive

\begin{tabular}{|c|c|c|c|c|c|c|}
\hline \multirow[b]{2}{*}{ Independent variables: } & \multicolumn{4}{|c|}{ Dependent variable: Average protection motive } & \multicolumn{2}{|c|}{$\begin{array}{l}\text { Model (4) } 95 \% \text { confidence } \\
\text { interval for B }\end{array}$} \\
\hline & (1) & (2) & (3) & (4) & Lower bound & Upper bound \\
\hline Open innovation component (1) & & $\begin{array}{c}.371 * * * \\
(.000)\end{array}$ & & $\begin{array}{l}.358^{* * *} \\
(.000)\end{array}$ & .175 & .541 \\
\hline Closed innovation component (2) & & & $\begin{array}{l}.263^{*} \\
(.018)\end{array}$ & $\begin{array}{l}.241^{*} \\
(.045)\end{array}$ & .045 & .436 \\
\hline Size sample $($ Large $=1 /$ SMEs $=0)$ & $\begin{array}{l}.385 \\
(.286)\end{array}$ & $\begin{array}{l}.529 \\
(.109)\end{array}$ & $\begin{array}{l}.185 \\
(.604)\end{array}$ & $\begin{array}{l}.341 \\
(.293)\end{array}$ & -.302 & .984 \\
\hline Size (LogTurnover) & $\begin{array}{l}-.171 \\
(.277)\end{array}$ & $\begin{array}{l}-.179 \\
(.208)\end{array}$ & $\begin{array}{l}.185 \\
(.604)\end{array}$ & $\begin{array}{l}-.144 \\
(.294)\end{array}$ & -.416 & .128 \\
\hline IP organization & $\begin{array}{l}.141 \\
(.152)\end{array}$ & $\begin{array}{l}.074 \\
(.408)\end{array}$ & $\begin{array}{l}.121 \\
(.203)\end{array}$ & $\begin{array}{l}.058 \\
(.500)\end{array}$ & -.113 & .230 \\
\hline Chemistry, Biotechnology, Pharmaceuticals & $\begin{array}{c}.619 \\
(.121)\end{array}$ & $\begin{array}{l}.819^{*} \\
(.026)\end{array}$ & $\begin{array}{c}.428 \\
(.272)\end{array}$ & $\begin{array}{l}.637^{+} \\
(.075)\end{array}$ & -.067 & 1.342 \\
\hline Electronics, IT, Power & $\begin{array}{l}.489 \\
(.187)\end{array}$ & $\begin{array}{l}.590^{+} \\
(.080)\end{array}$ & $\begin{array}{l}.292 \\
(.423)\end{array}$ & $\begin{array}{l}.406 \\
(.220)\end{array}$ & -.249 & 1.062 \\
\hline Mechanical & $\begin{array}{l}.704^{+} \\
(.059)\end{array}$ & $\begin{array}{l}.915^{* *} \\
(.008)\end{array}$ & $\begin{array}{l}.528 \\
(.147)\end{array}$ & $\begin{array}{l}.745^{*} \\
(.027)\end{array}$ & .089 & 1.402 \\
\hline Constant & $\begin{array}{c}3.526^{* * *} \\
(.000)\end{array}$ & $\begin{array}{c}3.451^{* * * *} \\
(.000)\end{array}$ & $\begin{array}{c}3.605^{* * *} \\
(.000)\end{array}$ & $\begin{array}{l}3.526^{* * *} \\
(.000)\end{array}$ & 1.951 & 5.101 \\
\hline Observations & 69 & 69 & 69 & 69 & & \\
\hline $\mathrm{R}^{2}$ & .128 & .302 & .205 & .366 & & \\
\hline Adjusted $\mathrm{R}^{2}$ & .043 & .222 & .113 & .281 & & \\
\hline
\end{tabular}


Table 5 Regression results - bargaining motive

\begin{tabular}{|c|c|c|c|c|c|c|}
\hline \multirow[b]{2}{*}{ Independent variables: } & \multicolumn{4}{|c|}{ Dependent variable: Average bargaining motive } & \multicolumn{2}{|c|}{$\begin{array}{c}\text { Model (4) } 95 \% \text { confidence } \\
\text { interval for B }\end{array}$} \\
\hline & (1) & (2) & (3) & (4) & Lower bound & Upper bound \\
\hline Open innovation component (1) & & $\begin{array}{l}.218^{+} \\
(.058)\end{array}$ & & $\begin{array}{l}.207^{+} \\
(.071)\end{array}$ & -.018 & .431 \\
\hline Closed innovation component (2) & & & $\begin{array}{l}.182 \\
(.133)\end{array}$ & $\begin{array}{l}.166 \\
(.162)\end{array}$ & -.069 & .401 \\
\hline Size sample $($ Large $=1 /$ SMEs $=0)$ & $\begin{array}{l}-.386 \\
(.321)\end{array}$ & $\begin{array}{l}-.284 \\
(.459)\end{array}$ & $\begin{array}{l}-.528 \\
(.184)\end{array}$ & $\begin{array}{l}-.419 \\
(.286)\end{array}$ & -1.199 & .360 \\
\hline Size (LogTurnover) & $\begin{array}{l}.056 \\
(.741)\end{array}$ & $\begin{array}{l}.048 \\
(.770)\end{array}$ & $\begin{array}{l}.082 \\
(.622)\end{array}$ & $\begin{array}{c}.073 \\
(.656)\end{array}$ & -.254 & .400 \\
\hline IP organization & $\begin{array}{l}.154 \\
(.142)\end{array}$ & $\begin{array}{c}.114 \\
(.276)\end{array}$ & $\begin{array}{l}.141 \\
(.177)\end{array}$ & $\begin{array}{c}.104 \\
(.318)\end{array}$ & -.103 & .310 \\
\hline Chemistry, Biotechnology, Pharmaceuticals & $\begin{array}{l}1.106^{*} \\
(.011)\end{array}$ & $\begin{array}{l}1.209^{* *} \\
(.005)\end{array}$ & $\begin{array}{l}.978^{*} \\
(.025)\end{array}$ & $\begin{array}{l}1.087^{*} \\
(.013)\end{array}$ & .242 & 1.931 \\
\hline Electronics, IT, Power & $\begin{array}{l}.865^{*} \\
(.032)\end{array}$ & $\begin{array}{l}.928^{*} \\
(.019)\end{array}$ & $\begin{array}{l}.728^{+} \\
(.073)\end{array}$ & $\begin{array}{l}.799^{*} \\
(.047)\end{array}$ & .012 & 1.586 \\
\hline Mechanical & $\begin{array}{l}.547 \\
(.167)\end{array}$ & $\begin{array}{l}.672^{*} \\
(.089)\end{array}$ & $\begin{array}{c}.424 \\
(.288)\end{array}$ & $\begin{array}{l}.553 \\
(.165)\end{array}$ & -.235 & 1.342 \\
\hline Constant & $\begin{array}{l}1.321 \\
(.179)\end{array}$ & $\begin{array}{l}1.284 \\
(.182)\end{array}$ & $\begin{array}{l}1.374 \\
(.158)\end{array}$ & $\begin{array}{l}1.335 \\
(.162)\end{array}$ & -.553 & 3.223 \\
\hline Observations & 68 & 68 & 68 & 68 & & \\
\hline $\mathrm{R}^{2}$ & .209 & .256 & .239 & .280 & & \\
\hline Adjusted $\mathrm{R}^{2}$ & .131 & .169 & .150 & .182 & & \\
\hline
\end{tabular}

Notes: Regression coefficients (unstandardized B), with significance in parentheses. $+, *, * *$, and $* * *$ indicate significance at the $10 \%, 5 \%, 1 \%$, and $0.1 \%$ levels, respectively. 
We can now complement these regression results with findings on two questions specifically asking the respondents about their perceptions of patents' enabling role for two specific types of open innovation. The average results for both questions are significantly above 0 at the $0.1 \%$ significance level, see Figure 2 . This indicates that the perception is that patenting new technologies typically increases possibilities for technology transfer and trade as well as for doing collaborative and joint R\&D work with other firms and/or other organizations.

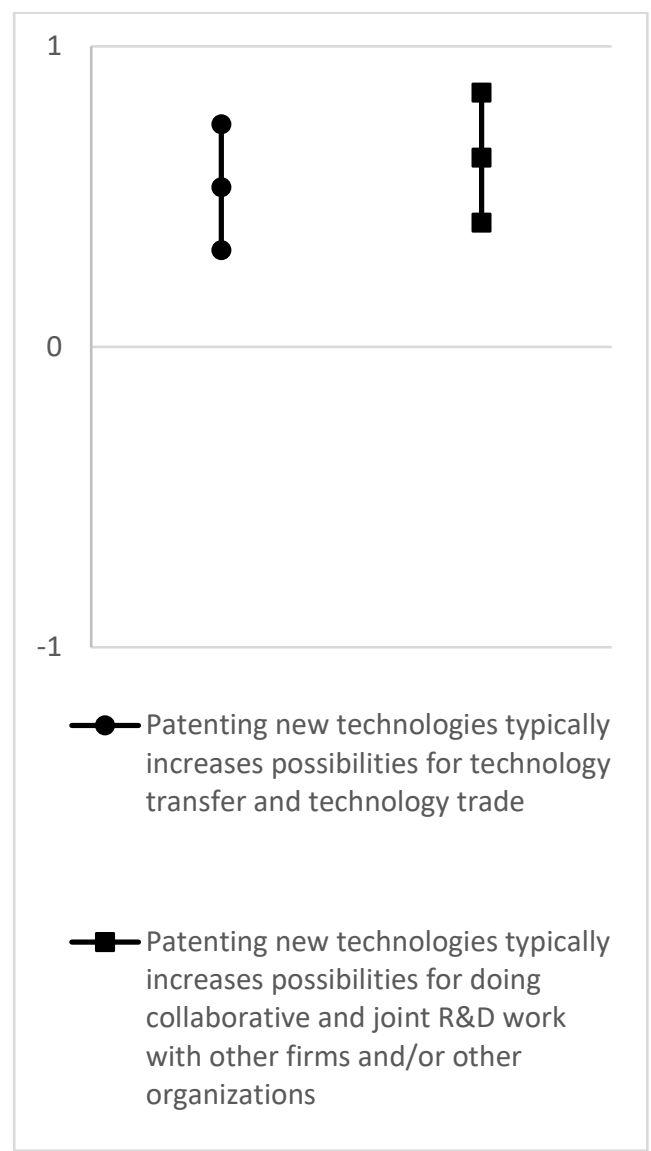

Figure 2 Respondents' agreement to statements (scale: $-2=$ completely disagree; $0=$ neither disagree, nor agree; $+2=$ completely agree), average values and $95 \%$ confidence intervals

We now allow ourselves to be a bit more explorative in our data analysis. Table 6 presents results from 21 regressions, one for each individual motive to patent as dependent variable, and using the same control variables as above with both the open and the closed innovation component as independent variables (analogous to model 4 in Table 4 and 5 above). The results show positive relationships between open innovation and all motives to patent, and patenting motives are more strongly positively related with open innovation than with closed innovation for all but one individual motive, namely the motive to attract customers. 
Table 6 Explorative analysis of (unstandardized) B coefficients and 95\% confidence intervals from linear regressions (with controls as above)

\begin{tabular}{|c|c|c|c|c|c|c|c|c|}
\hline & \multicolumn{4}{|c|}{ Open innovation component (1) } & \multicolumn{4}{|c|}{ Closed innovation component (2) } \\
\hline & B & Sig & $\begin{array}{l}\text { Lower } \\
\text { bound }\end{array}$ & $\begin{array}{l}\text { Upper } \\
\text { bound }\end{array}$ & B & Sig & $\begin{array}{l}\text { Lower } \\
\text { bound }\end{array}$ & $\begin{array}{l}\text { Upper } \\
\text { bound }\end{array}$ \\
\hline \multicolumn{9}{|l|}{ For protection: } \\
\hline a) i. Protecting product technology & $.510^{* * * *}$ & .000 & .313 & .707 & $.330^{* *}$ & .003 & .114 & .546 \\
\hline a) ii. Protecting process technology & .176 & .205 & -.099 & .452 & .092 & .543 & -.210 & .395 \\
\hline a) iii. Creating retaliatory power against competitors & $.279^{+}$ & .084 & -.038 & .597 & .271 & .116 & -.069 & .610 \\
\hline a) iv. Blocking competitors from certain technology areas & $.320^{*}$ & .021 & .051 & .589 & .083 & .567 & -.205 & .370 \\
\hline a) v. Securing freedom to operate & $.500^{* * *}$ & .000 & .257 & .742 & $.290^{*}$ & .029 & .031 & .549 \\
\hline \multicolumn{9}{|l|}{ For bargaining: } \\
\hline b) i. Giving better possibilities of selling licenses & .161 & .324 & -.163 & .485 & .148 & .365 & -.177 & .474 \\
\hline b) ii. Giving better possibilities of accessing technology through cross-licensing & .102 & .528 & -.219 & .423 & .067 & .687 & -.263 & .397 \\
\hline b) iii. Facilitating R\&D collaboration with others & $.418^{* *}$ & .002 & .162 & .673 & $.243^{+}$ & .074 & -.025 & .511 \\
\hline b) iv. Giving a better bargaining position in standard-setting & $.359^{*}$ & .040 & .017 & .701 & -.149 & .386 & -.490 & .192 \\
\hline \multicolumn{9}{|l|}{ For improving the corporate image towards: } \\
\hline c) i. Employees/new recruits & .171 & .198 & -.092 & .434 & .082 & .541 & -.186 & .351 \\
\hline c) ii. Customers & .084 & .615 & -.249 & .417 & .157 & .360 & -.184 & .498 \\
\hline c) iii. Suppliers & .064 & .596 & -.177 & .306 & -.198 & .113 & -.445 & .049 \\
\hline c) iv. Investors & $.268^{+}$ & .065 & -.017 & .554 & -.038 & .798 & -.332 & .256 \\
\hline c) v. Other collaborators & $.264^{*}$ & .046 & .005 & .523 & -.038 & .772 & -.304 & .227 \\
\hline c) vi. Local government(s) & .139 & .265 & -.109 & .388 &.$- .328^{*}$ & .015 & -.589 & -.066 \\
\hline \multicolumn{9}{|l|}{ For attracting external financing in form of: } \\
\hline $\begin{array}{l}\text { d) i. Bank loans and similar from non-governmental institutions without governmental } \\
\text { guarantees }\end{array}$ & $.428^{*}$ & .011 & .103 & .753 & -.256 & .144 & -.603 & .091 \\
\hline d) ii. Private equity/venture capital & $.356^{*}$ & .046 & .007 & .705 & -0.15 & .933 & -.376 & .345 \\
\hline d) iii. Governmental loans and grants and other loans with governmental guarantees & $.386^{*}$ & .015 & .079 & 693 & $-.256^{+}$ & .098 & -.561 & .049 \\
\hline d) iv. Governmental equity/venture capital & $.359^{*}$ & .013 & .081 & .636 & $-.264^{+}$ & .060 & -.540 & .012 \\
\hline \multicolumn{9}{|l|}{ For internal reasons: } \\
\hline e) i. Providing motivation for employees to invent & .177 & .238 & -.120 & .473 & .093 & .541 & -.210 & .397 \\
\hline e) ii. Providing a measure of $R \& D$ productivity & $.383^{*}$ & .020 & .063 & .703 & -.074 & .661 & -.409 & .261 \\
\hline
\end{tabular}

Notes: $+* * *$. and $* * *$ indicate significance at the $10 \% .5 \% .1 \%$. and $0.1 \%$ levels. respectively. 
Apart from protection motives and bargaining motives as discussed above, increasing importance of open innovation strategies is most notably related to increasing importance of motives related to attracting external financing, and the difference compared to closed innovation is significant when analyzing overlaps of confidence intervals (e.g., Cumming, 2009, Cumming and Finch, 2005).

In addition the explorative results show that the importance of open innovation is positively related to the importance of the patenting motives of attracting collaborators and of providing a measurement of $\mathrm{R} \& \mathrm{D}$ productivity, also significantly more than for closed innovation. It thus seems like patents as measures of $R \& D$ productivity is more important in open innovation settings than in closed ones.

\section{Concluding discussion}

This study of patent motives shows that the traditional motive to patent in order to protect product technology still dominates. This finding is in line with previous research (e.g., Arundel et al., 1995, Blind et al., 2006). However, the results also show that the motive to secure FTO is almost as important. Thus, even though the publication of patent applications is frequently referred to as an important downside with patenting, the resulting contribution to prior art relates to one of the most important motives to actually apply for a patent (cf. Holgersson and Wallin, 2017, Peters et al., 2013). The group of protection motives more generally (also including blocking competitors from certain technology areas and creating retaliatory power in addition to technology protection and safeguarding FTO) dominates over other motives (protection of process technologies being an exception). The protection motives are followed by image motives and then internal motives in average importance. These are followed by bargaining motives, including motives such as enabling licensing, cross-licensing, and R\&D collaborations. The least important group of motives on average is the one related to attracting external financing, although the latter is significantly more important for SMEs than for large firms, which also goes in line with previous research (e.g., Holgersson, 2013, de Rassenfosse, 2012).

The results from the statistical analysis, based on PCA and multiple linear regressions, support both our hypotheses, that (H1) the importance of protection motives and (H2) the importance of bargaining motives are positively related with the importance of open innovation strategies. The positive relationship between protection motives and open innovation is stronger than that between bargaining motives and open innovation. This goes somewhat in line with recent findings by de Rassenfosse et al. (2016), who found support for the claim that patents help protecting buyers against expropriation of the idea, while they did not find support for the claim that patents facilitate technology trade by enabling information 
sharing. On the other hand our results contrast results by Blind et al. (2006) who found that the frequency of $R \& D$ cooperation only explains exchange motives, not protection motives.

How come that protection in our study seems to be even more important than facilitation when patenting in open innovation? A number of explanations could be offered. First, the need for protection of the focal technology increases with the increasing imitation risks that open innovation entails (Veer et al., 2016). Second, the need for securing both FTO and technological flexibility increases as technologies across actors mix and converge (cf. Blind et al., 2006). Third, bargaining power in technology negotiations is closely related to the level of protection of the underlying technologies. Fourth, there are many other ways than patents of facilitating open innovation (Chesbrough et al., 2006), while open innovation limits other options than patents of protecting technology (Arundel, 2001, Hagedoorn and Zobel, 2015).

Our explorative statistical analysis furthermore shows that open innovation, or in other terms external technology strategies, is positively related to all individual motives to patent, and more so than closed innovation for all but one individual motive (attracting customers). In addition to the protection and bargaining motives discussed above, a notable result is the significantly larger positive relationship between open innovation and financing motives than between closed innovation and financing motives. This means that firms utilizing open innovation strategies find financing motives more important than firms utilizing closed innovation strategies. We propose two possible explanations behind this. First, firms utilizing open innovation might do so due to resource constraints, possibly meaning that they are not only in need of external technological and complementary resources but also of external financial resources, which in turn might force them to sell technology or company stock to finance their further developments. Second, firms engaged in open innovation might have learned how to utilize patent rights as contractual building blocks (e.g., Merges, 2011), and may thus be more aware than others of the possibilities to use that also in other settings, such as in financing, thereby increasing their propensity to patent on non-traditional grounds.

This study contributes both to a long-standing research stream of patenting motives and to a more recent stream of empirical research that investigates the role of patents in open innovation, addressing the question of whether patents enable or inhibit open innovation. Our results, showing that increasing use of open innovation is related to stronger motives to patent in general, and especially stronger motives to patent in order to protect product technologies and to secure FTO, complement previous findings, showing for example that there is (at least to some extent) a positive relationship between the importance/use of formal appropriation mechanisms and various measures of openness (Freel and Robson, forthcoming, 
Miozzo et al., 2016, Zobel et al., 2017), that new entrants with many patents engage in more innovation collaborations than others (Zobel et al., 2016), and that technological leaders are more prone than followers to increase their patenting when engaged in open innovation since they have more to lose from unintended knowledge spillovers (Arora et al., 2016).

To summarize our results support the view of patents mainly as enablers of open innovation for the individual innovating firm (Arrow, 1962, Chesbrough, 2003a, Gans et al., 2008), rather than the opposite view of patents mainly as hinders to sequential and cumulative innovation across firm boundaries (Baldwin and von Hippel, 2011, Brüggemann et al., 2016). ${ }^{8}$ However, we have not taken a welfare perspective but rather focused on individual firm strategies. Even though our results are not indicative in terms of whether or not patents are conducive for benefits from open innovation on a societal level, they are clearly indicating that for the individual firm the motives to patent are stronger in open innovation than in closed innovation.

\section{List of references}

ALEXY, O., CRISCUOLO, P. \& SALTER, A. 2009. Does IP strategy have to cripple open innovation? MIT Sloan Management Review, 51, 71-77.

ARORA, A., ATHREYE, S. \& HUANG, C. 2016. The paradox of openness revisited: Collaborative innovation and patenting by UK innovators. Research Policy, 45, 1352-1361.

ARORA, A. \& CECCAGNOLI, M. 2006. Patent Protection, Complementary Assets, and Firms' Incentives for Technology Licensing. Management Science, 52, 293-308.

ARORA, A., FOSFURI, A. \& GAMBARDELLA, A. 2001. Markets for Technology: The Economics of Innovation and Corporate Strategy, Cambridge, MA, MIT Press.

ARROW, K. J. 1962. Economic welfare and the allocation of resources for invention. In: NATIONAL BUREAU OF ECONOMIC RESEARCH (ed.) The Rate and Direction of Inventive Activity: Economic and Social Factors. Princeton, NJ: Princeton University Press.

ARUNDEL, A. 2001. The relative effectiveness of patents and secrecy for appropriation. Research Policy, 30, 611-624.

ARUNDEL, A. \& KABLA, I. 1998. What percentage of innovations are patented? Empirical estimates for European firms. Research Policy, 27, 127-141.

ARUNDEL, A., VAN DE PAAL, G. \& SOETE, L. 1995. Innovation Strategies of Europe's Largest Industrial Firms: Results of the PACE Survey for

\footnotetext{
${ }^{8}$ We see open innovation strategies as various external strategies to acquire and commercialize new technologies. Needless to say, if innovations need to be public goods to be defined as open, the results would be different (cf. Baldwin and von Hippel, 2011).
} 
Information Sources, Public Research, Protection of Innovations and Government Programmes, Maastricht, MERIT.

BALDWIN, C. Y. \& HENKEL, J. 2015. Modularity and intellectual property protection. Strategic Management Journal, 36, 1637-1655.

BALDWIN, C. Y. \& VON HIPPEL, E. 2011. Modeling a paradigm shift: From producer innovation to user and open collaborative innovation. Organization Science, 22, 1399-1417

BESSEN, J. \& MEURER, M. J. 2008. Patent Failure: How Judges, Bureaucrats, and Lawyers Put Innovators at Risk, Princeton, NJ, Princeton University Press.

BHASKARABHATLA, A. \& HEGDE, D. 2014. An Organizational Perspective on Patenting and Open Innovation. Organization Science, 25, 1744-1763.

BLIND, K., EDLER, J., FRIETSCH, R. \& SCHMOCH, U. 2006. Motives to patent: Empirical evidence from Germany. Research Policy, 35, 655-672.

BOGERS, M. 2011. The open innovation paradox: Knowledge sharing and protection in R\&D collaborations. European Journal of Innovation Management, 14, 93-117.

BOLDRIN, M. \& LEVINE, D. K. 2008. Against Intellectual Monopoly, Cambridge, MA, Cambridge University Press.

BOLDRIN, M. \& LEVINE, D. K. 2013. The case against patents. The journal of economic perspectives, 27, 3-22.

BROUWER, E. \& KLEINKNECHT, A. 1999. Innovative output, and a firm's propensity to patent.: An exploration of CIS micro data. Research Policy, 28, 615-624.

BRÜGGEMANN, J., CROSETTO, P., MEUB, L. \& BIZER, K. 2016. Intellectual property rights hinder sequential innovation. Experimental evidence. Research Policy, 45, 2054-2068.

BURK, D. L. \& LEMLEY, M. A. 2009. The patent crisis and how the courts can solve it, University of Chicago Press.

CERNY, B. A. \& KAISER, H. F. 1977. A study of a measure of sampling adequacy for factor-analytic correlation matrices. Multivariate Behavioral Research, 12, 43-47.

CHABCHOUB, N. \& NIOSI, J. 2005. Explaining the propensity to patent computer software. Technovation, 25, 971-978.

CHESBROUGH, H. W. 2003a. The logic of open innovation: Managing intellectual property. California Management Review, 45, 33-58.

CHESBROUGH, H. W. 2003b. Open Innovation: The New Imperative for Creating and Profiting from Technology, Boston, MA, Harvard Business School Press.

CHESBROUGH, H. W., VANHAVERBEKE, W. \& WEST, J. (eds.) 2006. Open Innovation: Researching a New Paradigm, Oxford: Oxford University Press.

COHEN, W. M., NELSON, R. R. \& WALSH, J. P. 2000. Protecting their intellectual assets: Appropriability conditions and why US manufacturing firms patent (or not). NBER Working Paper 7552.

CONTI, A., THURSBY, J. \& THURSBY, M. 2013. Patents as Signals for Startup Financing. The Journal of Industrial Economics, 61, 592-622. 
CUMMING, G. 2009. Inference by eye: reading the overlap of independent confidence intervals. Statistics in medicine, 28, 205-220.

CUMMING, G. \& FINCH, S. 2005. Inference by eye: confidence intervals and how to read pictures of data. American Psychologist, 60, 170-180.

DAHLANDER, L. \& GANN, D. M. 2010. How open is innovation? Research Policy, 39, 699-709.

DE RASSENFOSSE, G. 2012. How SMEs exploit their intellectual property assets: evidence from survey data. Small Business Economics, 39, 437452.

DE RASSENFOSSE, G., PALANGKARAYA, A. \& WEBSTER, E. 2016. Why do patents facilitate trade in technology? Testing the disclosure and appropriation effects. Research Policy, 45, 1326-1336.

DUGUET, E. \& KABLA, I. 1998. Appropriation strategy and the motivations to use the patent system: An econometric analysis at the firm level in French manufacturing. Annals of Economics and Statistics / Annales d'Économie et de Statistique, 289-327.

DZIUBAN, C. D. \& SHIRKEY, E. C. 1974. When is a correlation matrix appropriate for factor analysis? Some decision rules. Psychological bulletin, 81, 358.

ENKEL, E., GASSMANN, O. \& CHESBROUGH, H. W. 2009. Open R\&D and open innovation: Exploring the phenomenon. $R \& D$ Management, 39, 311316.

FOSS, N. J., HUSTED, K. \& MICHAILOVA, S. 2010. Governing Knowledge Sharing in Organizations: Levels of Analysis, Governance Mechanisms, and Research Directions. Journal of Management Studies, 47, 455-482.

FREEL, M. S. \& ROBSON, P. forthcoming. Appropriation strategies and open innovation in SMEs. International Small Business Journal.

GANS, J. S., HSU, D. H. \& STERN, S. 2008. The Impact of Uncertain Intellectual Property Rights on the Market for Ideas: Evidence from Patent Grant Delays. Management Science, 54, 982-997.

GRANSTRAND, O. 1982. Technology, Management and Markets: An Investigation of $R \& D$ and Innovation in Industrial Organizations, London, Frances Pinter.

GRANSTRAND, O. 1999. The Economics and Management of Intellectual Property: Towards Intellectual Capitalism, Cheltenham, Edward Elgar Publishing.

GRANSTRAND, O. 2004. The economics and management of technology trade: Towards a pro-licensing era? International Journal of Technology Management, 27, 209-240.

GRANSTRAND, O. 2006. Intellectual property rights for governance in and of innovation systems. In: ANDERSEN, B. (ed.) Intellectual Property Rights: Innovation, Governance and the Institutional Environment. Cheltenham: Edward Elgar Publishing.

GRANSTRAND, O., BOHLIN, E., OSKARSSON, C. \& SJÖBERG, N. 1992. External technology acquisition in large multi-technology corporations. $R \& D$ Management, 22, 111-133. 
GRANSTRAND, O. \& HOLGERSSON, M. 2012. The anatomy of rise and fall of patenting and propensity to patent: The case of Sweden. International Journal of Intellectual Property Management, 5, 169-198.

GRANSTRAND, O. \& HOLGERSSON, M. 2013. Managing the intellectual property disassembly problem. California Management Review, 55, 184210.

GRANSTRAND, O. \& HOLGERSSON, M. 2014. The challenge of closing open innovation: The intellectual property disassembly problem. ResearchTechnology Management, 57, 19-25.

GRANSTRAND, O. \& SJÖLANDER, S. 1990. Managing innovation in multitechnology corporations. Research Policy, 19, 35-60.

HAGEDOORN, J. \& ZOBEL, A.-K. 2015. The role of contracts and intellectual property rights in open innovation. Technology Analysis \& Strategic Management, 27, 1050-1067.

HALL, B. H. 2004. Exploring the patent explosion. Journal of Technology Transfer, 30, 35-48.

HENKEL, J. 2006. Selective revealing in open innovation processes: The case of embedded Linux. Research Policy, 35, 953-969.

HENKEL, J., BALDWIN, C. Y. \& SHIH, W. 2013. IP modularity: Profiting from innovation by aligning product architecture with intellectual property. California Management Review, 55, 65-82.

HOENIG, D. \& HENKEL, J. 2015. Quality signals? The role of patents, alliances, and team experience in venture capital financing. Research Policy, 44, 1049-1064.

HOLGERSSON, M. 2012. Innovation and Intellectual Property: Strategic IP Management and Economics of Technology. PhD, Chalmers University of Technology.

HOLGERSSON, M. 2013. Patent management in entrepreneurial SMEs: a literature review and an empirical study of innovation appropriation, patent propensity, and motives. $R \& D$ Management, 43, 21-36.

HOLGERSSON, M., PHAN, T. \& HEDNER, T. 2016. Entrepreneurial patent management in pharmaceutical startups. Drug Discovery Today, 21, 10421045.

HOLGERSSON, M. \& WALLIN, M. W. 2017. The patent management trichotomy: Patenting, publishing, and secrecy. Management Decision.

HU, A. G. \& JEFFERSON, G. H. 2009. A great wall of patents: What is behind China's recent patent explosion? Journal of Development Economics, 90, 57-68.

JAFFE, A. B. \& LERNER, J. 2004. Innovation and Its Discontents: How Our Broken Patent System Is Endangering Innovation and Progress, and What to Do About It, Princeton, NJ, Princeton University Press.

JELL, F., HENKEL, J. \& WALLIN, M. W. forthcoming. Offensive Patent Portfolio Races. Long Range Planning.

KEUPP, M. M., LHUILLERY, S., GARCIA-TORRES, M. A. \& RAFFO, J. 2009. SME-IP 2nd Report: Economic Focus Study on SMEs and Intellectual Property in Switzerland, Publication No 5 (06.09), Swiss Federal Institute of Intellectual Property. 
KITCHING, J. \& BLACKBURN, R. 1998. Intellectual property management in the small and medium enterprise (SME). Journal of Small Business and Enterprise Development, 5, 327-335.

KORTUM, S. \& LERNER, J. 1998. Stronger protection or technological revolution: what is behind the recent surge in patenting? CarnegieRochester Conference Series on Public Policy, 48, 247-304.

LEVIN, R. C., KLEVORICK, A. K., NELSON, R. R. \& WINTER, S. G. 1987. Appropriating the returns from industrial research and development. Brookings Papers on Economic Activity, 14, 783-831.

MANSFIELD, E. 1986. Patents and innovation: An empirical study. Management Science, 32, 173-181.

MANZINI, R. \& LAZZAROTTI, V. 2015. Intellectual property protection mechanisms in collaborative new product development. $R \& D$ Management, n/a-n/a.

MERGES, R. P. 2011. Justifying Intellectual Property, Cambridge, Massachusetts, Harvard University Press.

MIHM, J., STING, F. J. \& WANG, T. 2015. On the Effectiveness of Patenting Strategies in Innovation Races. Management Science, 61, 2662-2684.

MIOZZO, M., DESYLLAS, P., LEE, H.-F. \& MILES, I. 2016. Innovation collaboration and appropriability by knowledge-intensive business services firms. Research Policy, 45, 1337-1351.

PETERS, T., THIEL, J. \& TUCCI, C. L. 2013. Protecting Growth Options in Dynamic Markets: The role of strategic disclosure in integrated intellectual property strategies. California Management Review, 55, 121142.

PISANO, G. P. \& TEECE, D. J. 2007. How to capture value from innovation: Shaping intellectual property and industry architecture. California Management Review, 50, 278-296.

TEECE, D. J. 1986. Profiting from technological innovation: Implications for integration, collaboration, licensing and public policy. Research Policy, 15, 285-305.

THUMM, N. 2004. Motives for patenting biotechnological inventions: an empirical investigation in Switzerland. International Journal of Technology, Policy and Management, 4, 275-285.

TIETZE, F. 2012. Technology Market Transactions, Cheltenham, Edward Elgar Publishing.

VEER, T., LORENZ, A. \& BLIND, K. 2016. How open is too open? The mitigating role of appropriation mechanisms in $\mathrm{R} \& \mathrm{D}$ cooperation settings. $R \& D$ Management, $\mathrm{n} / \mathrm{a}-\mathrm{n} / \mathrm{a}$.

WEST, J. 2006. Does appropriability enable or retard open innovation? In: CHESBROUGH, H. W., VANHAVERBEKE, W. \& WEST, J. (eds.) Open Innovation: Researching a New Paradigm. Oxford: Oxford University Press.

WILLIAMSON, O. E. 1975. Markets and Hierarchies: Analysis and Antitrust Implications, New York, NY, Free Press.

VON HIPPEL, E. 2005. Democratizing Innovation, Cambridge, MA, MIT Press. 
VON HIPPEL, E. \& VON KROGH, G. 2006. Free revealing and the privatecollective model of innovation incentives. $R \& D$ Management, 36, 295306.

ZOBEL, A.-K., BALSMEIER, B. \& CHESBROUGH, H. 2016. Does patenting help or hinder open innovation? Evidence from new entrants in the solar industry. Industrial and Corporate Change, 25, 307-331.

ZOBEL, A.-K., LOKSHIN, B. \& HAGEDOORN, J. 2017. Formal and informal appropriation mechanisms: The role of openness and innovativeness. Technovation, 59, 44-54. 